\title{
乳酸菌のアスパラギン酸脱炭酸
}

\author{
樋口 猛*，内田金治，阿部敬悦 \\ キッコーマン株式会社研究本部 \\ 干278-0037 千葉県野田市野田 399
}

\begin{abstract}
酱油乳酸菌 Tetragenococcus halophilusの一部の菌株は奨油諸味中のアスパラギン酸を脱炭酸し，ア ラニンに変換する。この変換は奨油の味をマイルドにする, 奨油醸造にとって有用な反応である。

アスパラギン酸脱炭酸を引き起こす株 (Asd ${ }^{+}$株) であるD10株は，キュアリング処理により，多くのア スパラギン酸脱炭酸を引き起こさない株（Asp-株）を生じる。この株のアスパラギン酸脱炭酸性は $22 \mathrm{~kb}$ のプラスミドpD1上にコードされており，アスパラギン酸輸送体遺伝子と脱炭酸酵素がオペロンを形成し ていた。

D10株のような $\mathrm{Asd}^{+}$株は, 連続的に工業使用したいところであるが, 特定の乳酸菌株の連続使用は, ファー ジ污染をしばしば引き起こす。そこでD10株を親株としてファージ抵抗性株を育種した。育種された变異 株は奨油諸味仕込試験で良好な性質を示した。

醤油乳酸菌のアスパラギン酸脱炭酸の生理的意義は不明確であるが，アスパラギン酸脱炭酸を引き起こ す別の乳酸菌Lactobacillus subsp. M3 株では，アスパラギン酸：アラニンの対向輸送に伴い, proton-motive forceの形でエネルギー生成に寄与している事が明らかになった。奨油乳酸菌のアスパラ ギン酸脱炭酸でも同様の事が起こっている事が予想された。
\end{abstract}

乳酸菌の中には，特定のアミノ酸を脱炭酸するものが 見られる。これらの菌は多くの場合, 食品衛生上, 好ま しくないアミン類を生成する污染乳酸菌として知られる。 たとえば，肉製品を腐敗させる乳酸菌やチーズの乳酸発 酵中の污染乳酸菌による，上スチジンからヒスタミンへ の脱炭酸やチロシンからチラミンへの脱炭酸)などであ る。

これに対して，乳酸菌のアミノ酸脱炭酸の中でも，奨 油乳酸菌 Tetragenococcus halophilusによる滰油諸味 中のアスパラギン酸のアラニンへの脱炭酸は，奨油をよ りマイルドなむのに仕上げるという意味で産業上重要な 反応である2。本稿では酱油乳酸菌を中心に乳酸菌のア スパラギン酸脱炭酸に関する研究について紹介する。

\section{1. 酱油乳酸菌のアスパラギン酸脱炭酸とその有用性}

奨油は醇造工程に扔いて，その主発酵である酵母発酵 に先立って奨油乳酸菌 T. halophilusによる乳酸発醉が

*To whom correspondence should be addressed.

Phone: + 81-471-58-9123

Fax : +81-471-58-9124

E-mail :7490@mail.kikkoman.co.jp
起こる。T. halophilus は, 菌株ごとに糖発醅能, 諸味 還元性，有機酸代謝性が異なる ${ }^{\text {) }}$ という代謝的にみて非 常に多様な乳酸菌である。このような菌株ごとに異なる 代謝能は酱油品質に微妙に影響するが，その中でも特に 奨油品質に良い影響を与えるものとして，アスパラギン 酸の脱炭酸性が挙げられる3。

乳酸発酵前の奨油諸味中には, 主として大豆タンパク 質の分解に由来する $30-50 \mathrm{mM}$ 程度のアスパラギン酸を 含むが, 乳酸発酵後には諸味によってはアスパラギン酸 をほとんど含まないものもある。このような㽜油諸味中 には多くの場合, 通常の諸味よりアラニンが多い。これ は，アスパラギン酸脱炭酸性乳酸菌株 (Asd ${ }^{+}$株) が, 酱油乳酸菌の主要フローラとして生育した場合に起こる。 これらの $\mathrm{Asd}^{+}$株は，酸味のある酸性了ミノ酸アスパ ラギン酸を脱炭酸し，甘みのあるアラニンを生成するた め，醤油をまろや加するといわ机る。ちょうど，ワイ ンがマロラクティック発酵（ワイン中のリンゴ酸が乳酸 菌により脱炭酸されて乳酸になる発酵）によってまろや かになるのと類似した現象である。したがってアスパラ ギン酸脱炭酸性の酱油乳酸菌を奨油酾造で使いこなすこ とは, 奨油品質の改善およびその多樣化の為に有用であ 
る。

\section{2. アスパラギン酸分解性プラスミド $\mathrm{pD1}$}

酱油乳酸菌のアスパラギン酸脱炭酸性の遺伝的背景は 明かではなかった。しかしながら $\mathrm{Asd}^{+}$株の植元継ぎを 重祖ることにより脱炭酸性を欠落した株 (Asd'株) が出 現することや，またひとたび Asd-株になった株は再び $\mathrm{Asd}^{+}$株には戻らないことが経験的に知られていたので, プラスミド上にコードされている可能性が考えられてい た。そこで，キュアリング剤によりアスパラギン酸脱炭 酸性の脱落頻度が上昇するが゙うか，代表的な $\mathrm{Asd}^{+}$株 であるT. halophilus D10株について実験を行った。そ
の結果, キュアリング剂無添加区での Asd脱落率が $3 \%$ であったのに対し，キュアリング剂として $10 \mu \mathrm{g} / \mathrm{ml} の$ ethidium bromideを添加した時，46\%と高頻度の Asd 脱落が観察された。この時得られた，Asd株 6 株と, 脱落しなかった株 Asd株 6 株について，そのプラスミ ドプロフィールを調べた。 $\mathrm{Asd}^{+}$株では親株と同様に 3 本のプラスミドバンドが観察されたのに対して， $\mathrm{Asd}^{-}$ 株では一番大きいプラスミドバンドが脱落していた（网 1)。このことから，このプラスミド上に Asd遺伝子が コードされているむのと推定された。このプラスミドを $\mathrm{pD} 1$ と名付けた。

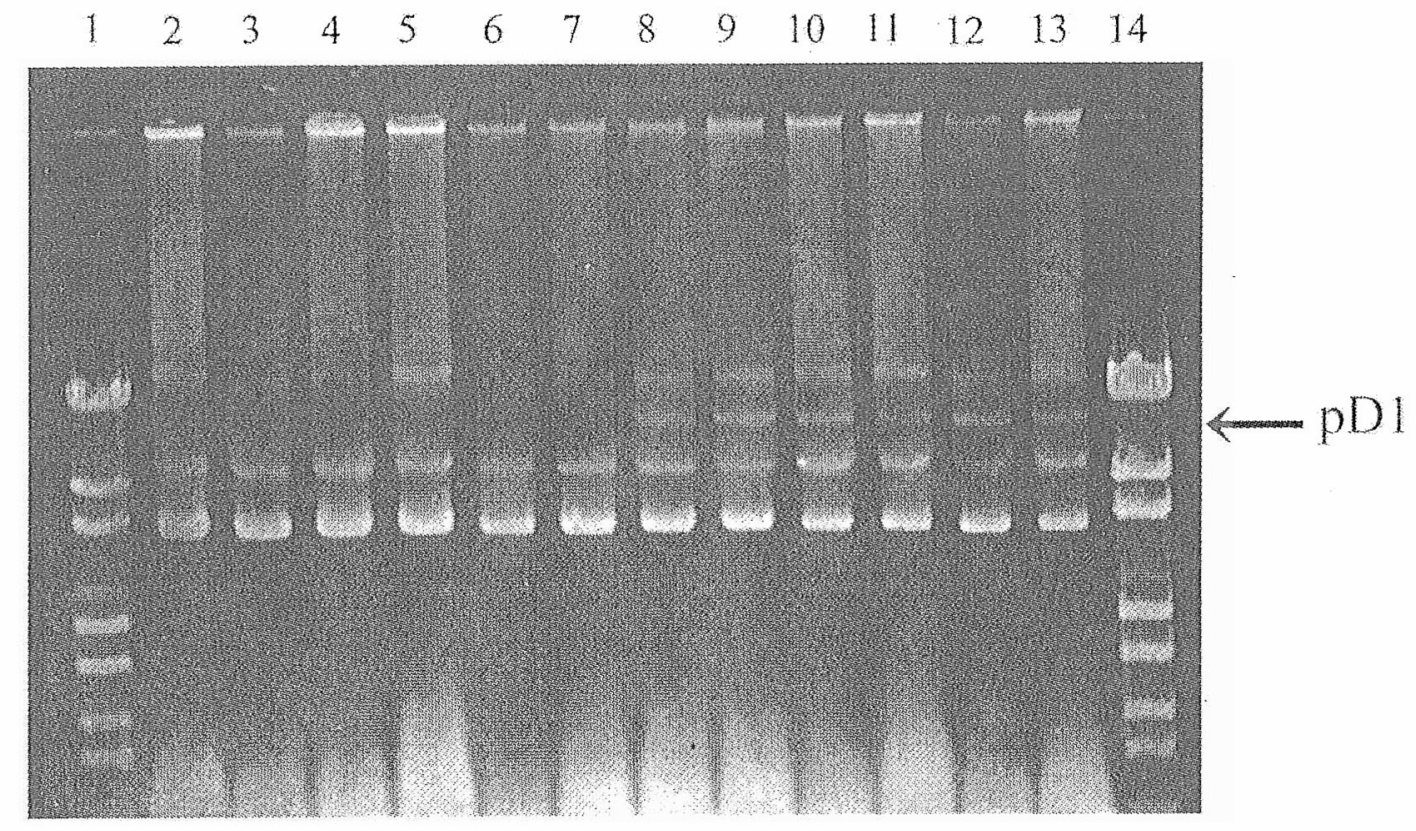

図 1.アスパラギン酸脱炭酸菌株D10株のキュアリング株のプラスミドプロフィール

lanes ; 1 and 14, EcoT14-digested $\lambda$ phage DNA.

lanes 2-7; $\mathrm{Asd}^{-}$isolates (Asd-1-Asd ${ }^{-}$)

lanes 8-13; $\mathrm{Asd}^{+}$isolates ( $\mathrm{Asd}^{+} 1-\mathrm{Asd}^{+} 6$ )

プラスミド pD1 は 2 個所の SalI サイトを持ち, 約 $10 \mathrm{~kb}$ と $12 \mathrm{~kb}$ のラグメントが得られたので, pD1 は約 22kbの大きさと推定された。SalI 切断による小さい方 の10Kbのフラグメントの塩基配列を決定したところ， このフラグメントには，少なくとあ 2 つオオープンリー ディングフレーム (ORF) が含まれていた。配列から 予想される遺伝子配列の模式図を図 2 に示した。遺伝子 は次のように並んでいた。

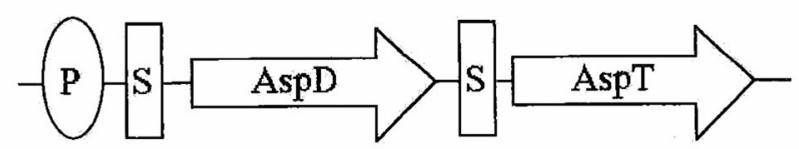

図 2.T. halophilus D10のプラスミドpD1の10kb-Sall 断片に含まれるアスパラギン酸脱炭酸関連遺伝子オペロ ンの推定構造

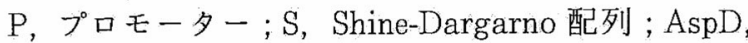
アスパラギン酸デカルボキシラーゼ遺伝子；AspT，ア スパラギン酸輸送体遺伝子 
1）プロモーター様配列

2) 一っ目の SD 配列

3）最初の ORF (AspD)

4) 二っ目の $S D$ 配列

5) 二っ目の ORF (AspT)

一つ目の ORF（AspD）上り予想されるアミノ酸配列 についてホモロジー検索を行ったところ, 既知のアスパ ラギン酸アミノトランスフェラーゼと相同性がみられた。 アミノ酸アミノトランスフェラーゼとアミノ酸デカルボ キシラーゼはアミノ酸配列上，非常に近縁の酵素である と考えらているすことからから AspD はアスパラギン酸 デカルボキシラーゼの遺伝子と推定した。

一方，二っ目の ORF（AspT）より予想されるタンパ ク質のアミノ酸配列は 12 個の Transmembranespanning region と思われる構造を持っていた。この構 造は膜に存在する輸送担体にしばしばみられるた。 。従っ て, AspTは何らかの輸送担体であることが予想された。

以上をまとめると，これらの遺伝子は AspD がアスパ ラギン酸デカルボキシラーゼ，AspTがアスパラギン酸

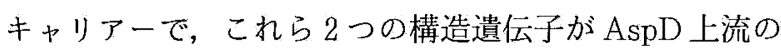
プロモーターから転写される1つのオペロンを形成して いると予想された。

AspD， T を含むDNA 断片を大腸菌において，

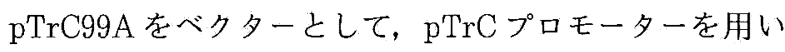
て発現させたところ，アスパラギン酸からアラニンへの 変換が観察されたりことからも，このAspD, Tがアス パラギン酸脱炭酸オペロンであることが支持された。な お，大きい方の $12 \mathrm{~kb}$ の Sal I フラグメントからは脱炭酸 酵素や輸送体タンパク質に相同性のある配列は見出され なかったり。

なお，これらの遺伝子がアスパラギン酸脱炭酸遺伝子 群であることを完全に証明するためには，これらの遺伝 子をT. halophilusで発現する必要があろうかと思われ るが，T. halophilus は形質転換系自体が未だ報告がな い。今後の研究が待たれるところである。

醤油乳酸菌 T. halophilusにはこれまで cripticなプ ラスミドしか見出されていなかった。また, 乳酸菌のア ミノ酸脱炭酸能がプラスミド上にコードされている例む これまで報告されていなかった。そうした意味でpD1 は 非常に興味深い性質を持ったプラスミドである。

なお，D10株に限らず，一般にT. halophilus のアス パラギン酸脱炭酸性は遺伝的に不安定で，植え継ぎ時に しばしば欠損することから，D10株以外の多くのアスパ ラギン酸脱炭酸性菌株でも，アスパラギン酸脱炭酸性は プラスミド上にコードされていることが推定される。

\section{3. アスパラギン酸脱炭酸性株 T. halophilus D10株の}

\section{ファージ抵抗性菌株の育種 ${ }^{8)}$}

チーズの乳酸発酵で良く知られるていることであるが, 特定の乳酸菌株を連続的に使用すると, バクテリオファー ジ污染がしばしば発生する9。奨油乳酸菌 T. halophilus にもバクテリオファージの存在が報告されており,こう したファージによる滰油諸味の污染は, 乳酸発酵不全や, 添加乳酸菌ではない乳酸菌の生育をむたらす10。

アスパラギン酸脱炭酸性株は, 諲油の品質改善に有用 な乳酸菌であるが，工業レベルで連続的に優先フローラ として酱油諸味中に生育させるためには，バクテリオファー ジ対策が必要である。そこでアスパラギン酸脱炭酸性株 T. halophilus D10株のファージ抵抗性菌株の育種を試 みた。

はじめに, 現場由来のファージ存在下で, プレート上 に生育したコロニーをファージ抵抗性株として分離した。 しかしながら,この方法で得られた抵抗株の中には選択 のために使用したファージ（もしくはその遺伝子）が乳 酸菌之共存している株が含まれており，一部の抵抗性株 からのファージの放出が見られた。このようなファージ 共存株は, 諸味中で溶菌したり, ファージを放出したり する可能性があり，実用株としては不適当と考えられた。

そこで, ファージやファージ遺伝子を含まないファー ジ抵抗性株を選択するために, 供試株とファージを直接 接触させないレプリカ法によるファージ抵抗性株育種を 試みた。

親株 T. halophilus D10を NTGにより变異処理した 後, 1次スクリーニングとして, NTG 処理した菌のコ ロニーを，あらかじめファージ溶菌液を塗布しておいた 選択プレートにレプリカし，そこで生育したコロニーに 対応する株を, 元のコロニーより選抜した。約150,000 コロニーから1500株のファージ抵抗性候補株を選抜した が,これらの株にはファージ抵抗性の無い株や弱い株, 増殖そのあのが弱い株が含まれていた。

そこで，2次スクリーニングとして候補株をファージ 存在下で生育させた時の増殖曲線を調べ，ファージ共存 下の親株と同等の増殖曲線を示す株をファージ抵抗性株 として選抜した。

その結果No.1とNo.4の 2 株が選抜された。これらの 株の増殖曲線を図 3 に示した。両株ともファージ存在下 であ親株之同等の生育を示した。またアスパラギン酸脱 炭酸能を確認したが両株とも親株と同様のアスパラギン 酸脱炭酸能を有していた。

そこで，両株を用いて実際に酱油諸味の小仕込み試験 を行った。 $10^{5} \mathrm{PFU} / \mathrm{ml}$ のファージ共存下でも両株とも ファージ非存在下での親株と同等の菌数増加と $\mathrm{pH}$ 低下 を示した（図 4 )。この時点で諸味の香りを官能的に調べ たところ, ファージ抵抗性変異株による諸味は親株によ 


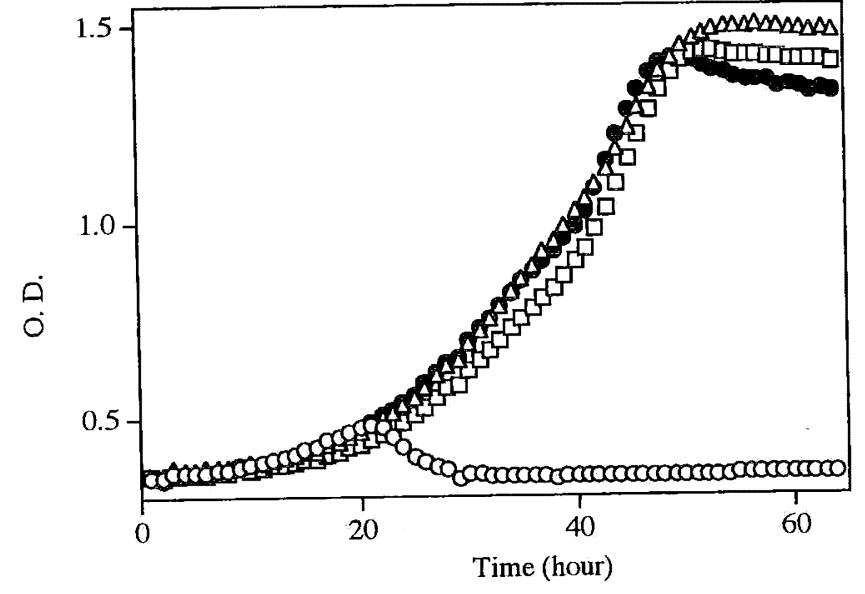

図 3. $\phi$ D-10共存下でのファージ抵抗性菌株の成長曲線 乳酸菌は約 $10^{7} \mathrm{CFU} / \mathrm{ml}$, ファージは約 $10^{6} \mathrm{PFU} / \mathrm{ml}$ 接種した。菌の生育はO.D.600nmで測定した。 Symbols : $\bigcirc, D 10$ (親株); $\triangle$, No. 1 株 ;

$\square$, No. 4 株; ○, D10, ファージ無添加

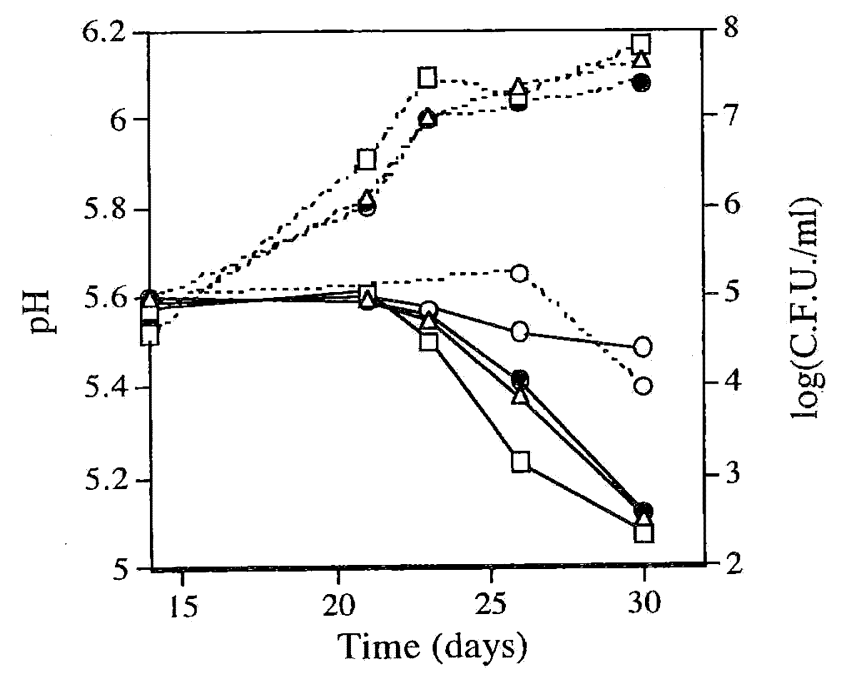

図 4.ファージ抵抗性菌株の輏油諸味仕込試験における 乳酸菌の生育と諸味 $\mathrm{pH}$ 変化

乳酸菌は約 $10^{5} \mathrm{CFU} / \mathrm{ml}$ ，ファージは約 $10^{6} \mathrm{PFU} / \mathrm{ml}$ で接種した。

Symbols : $\bigcirc$, D10 (親株) ; $\triangle$, No. 1 株;

$\square$, No. 4 株 ; - D10, ファージ無添加 ; 実線, $\mathrm{pH}$; 破線, 乳酸菌数

るあのと同等であった。さらに諸味の主発酵（酵母発酵） 終了後あるいは仕込み後 6 ケ月の熟成諸味においてあ, 親株添加区とファージ抵抗性変異株添加区との間で官能 的な違いは見られなかった。また，変異株を添加した諸
味で屯親株を添加した諸味同様, 諸味中のアスパラギン 酸はほぼ消失し，それに相当するモル数のアラニンの増 加が見られた。

以上の結果より，ファージ抵抗性変異株No.1, No. 4 は酱油醇造に使用しうる, 優良なアスパラギン酸脱炭酸 菌株であると思われた。

なお，ファージ抵抗性株の多くは細胞表層構造の変異 によりファージが吸着できなくなった変異株であること が知られている11)が，No.1，4株に関してはファージ吸 着能の低下は観察されておらず, ファージ吸着後のファー ジ増殖過程のどこかが阻害されていると考えられた。

\section{4. 乳酸菌のアスパラギン酸脱炭酸に伴うエネルギー獲} 得 ${ }^{12)}$

ところで, 奨油乳酸菌にとってアスパラギン酸を脱炭 酸してアラニンにすることは，どのような意味があるの だろうか?

ワイン乳酸菌のマロラクティック発酵はリンゴ酸から 乳酸への脱炭酸反応である。マロラクティック発酵乳酸 菌の一種であるLactobacillus plantarum のマロラク ティック発酵においては, 脱炭酸に伴い, 細胞内ATP が増加することが観察された ${ }^{13)}$ 。

我々は, 奨油乳酸菌でも同様のことが観察できるので はないかと考元, $\mathrm{Asd}^{+}$株, T. halophilus D10株の飢餓 菌体にアスパラギン酸を与え, 細胞内 ATP の変化を測 定したが，はっきりした変化はとらえられなかった。し かしながら，T. halophilusのアスパラギン酸脱炭酸活 性は彺弱なため，ATP濃度变化として捕らえられなかっ た可能性が考えられた。そこで，より強いアスパラギン 酸脱炭酸活性を有する乳酸菌について同様の実験を行っ た。

減塩した奨油や奨油をべースにした調味料は，乳酸菌 污染により発泡事故を起こすことがある(4)。これらの乳 酸菌は，奨油中のアスパラギン酸むしくはグルタミン酸 を脱炭酸することにより， $\mathrm{CO}_{2}$ を発生させて発泡を引き 起こす。奨油諸味のアスパラギン酸を数週間かけて脱炭 酸する奨油乳酸菌に比較して，数日でガラス瓶を破裂さ せるほど強烈な発泡を引き起こすこれらの污染乳酸菌は， 格段に強いアスパラギン酸脱炭酸活性を持つと推定され る。そこで，このようなアスパラギン酸脱炭酸菌の一種 であるLactobacillus sp. M3株で実験を行った。

M3株の菌懸濁液を，飢餓状態においた後，アスパラ ギン酸を与えたところ，表 1 に示すように，細胞内 ATP 濃度の上昇が観察された。このエネルギー生成は 脱共役剂 carbonyl cyanide- $m$-chlorophenylhydrazone (CCCP) や, 細胞内外のpH差消去剂バリノマイシンと 膜電位消去剤ナイジェライシンの同時添加により阻害さ 
表 1. Lactobacillus subsp. M3 株のアスパラギン酸脱炭酸に伴う ATP 生成と各種薬剤の影響

\begin{tabular}{|c|c|}
\hline 添加薬剤 & $\begin{array}{c}\text { 細胞内 ATP 濃度 } \\
\text { (nmol/mg dry weight) }\end{array}$ \\
\hline アスパラギン酸添加前 & 0.3 \\
\hline イオノフォア無添加 & 25.3 \\
\hline $1 \mathrm{mM}$ DCCD* & 8.7 \\
\hline $2 \mu \mathrm{M}$ nigericin $+2 \mu \mathrm{M}$ valinomycin & 0.3 \\
\hline $2 \mu \mathrm{M} \mathrm{CCCP}^{* *}$ & 0.3 \\
\hline
\end{tabular}

*dicyclohexylcarbodiimide

** carbonyl cyanide- $m$-chlorophenylhydrazone

れた。この時，アスパラギン酸脱炭酸反応そのものは阻 害されていなかったことから，このATP生成には proton-motive force が関与していると考えられた。

このような proton-motive force関与のエネルギー生 成機構として, Anantharam らによって発見された, 電気的に不等価な交換輸送による proton-motive force の発生が考えられる占。彼らは Oxalobactor formigenesがシュウ酸を蟻酸に脱炭酸する時に, 電気 的に不等価な交換輸送によりエネルギーが発生すること を示した。同様のことがLactobacillus sp. M3株であ 起こっていることを確認するために，M3株の膜タンパ ク質を抽出し，プロテオリポソームに再構成して，この 株のアスパラギン酸輸送の性質を調べた。

あらかじめアラニンをロードしておいたプロテオリポ ソームはアスパラギン酸を能動的に取込んだ。プロテオ リポソームの外側が負になるように膜電位をかけるとこ の取込みは促進され，外側を正に膜電位をかけると抑制 された。このことから，アスパラギン酸の輸送がアスパ ラギン酸の脱炭酸生成物であるアラニンとの交換輸送で あること，また，この交換輸送により電荷が発生するこ と，すなわちこの交換輸送が電気的に不等価であること が示された。電気的に不等価な交換輸送が起これば, 膜 電位を発生するので, 結果的にこの輸送系は proton-motive forceを生み出していることになる。さ らに脱炭酸反応により水素イオンがアラニン分子に固定 されることによってあ膜内外に $\mathrm{pH}$ 差が発生し，ここで 屯 proton-motive forceが発生する。こうしたことから, 下記のような機構でアスパラギン酸脱炭酸に伴うATP 生成が起こっていることが推定された（図５）。

1. アスパラギン酸とアラニンの $1: 1$ 対向輸送により細 胞の外側が正に荷電するような膜内外の電位差 $(\Delta \Psi)$ が生じる。

2. 細胞質内でのアスパラギン酸脱炭酸によりアスパラ ギン酸の $\alpha$-carboxyl 基が脱炭酸され，その部位に
細胞質のプロトンが入ることで, 細胞質中のプロト ンが消費され，細胞内がアルカリ性になるような膜 内外のpH差 $(\Delta \mathrm{pH})$ が生じる。

3. 1,2 で生じたプロトン駆動力 $(\Delta \mathrm{p})$ が $\mathrm{F}_{1} \mathrm{~F}_{0}$-ATPase により ATP 合成に利用される。

4. diffusionにより細胞内の $\mathrm{CO}_{2}$ は細胞外に出てゆく。

この反応において，アスパラギン酸の取込みエネルギー は反応生成物のアラニンの細胞内外の濃度差であり，ア ラニンの放出に伴い，反応基質であるアスパラギン酸は ますます細胞内に供給される。しかも，反応に伴い細胞 内外の電位差と水素イオン濃度差が蓄積し, ATP 生成 に使われるという，非常に効率の良いシステムである。

減塩酱油を発泡させる乳酸菌には，M3株に代表され るアスパラギン酸脱炭酸菌のほかに，グルタミン酸を $\gamma$ アミノ酪酸（GABA）に脱炭酸する乳酸菌が知られてい

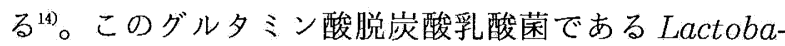
cillus sp. E1株に関しても，グルタミン酸の投与により 菌体内 ATP 濃度が上昇すること，この ATP 生成がイ オノフォアにより阻害されること，外部に高濃度の GABA が存在すると.ATP生成が起こらないことから， アスパラギン酸脱炭酸菌と同様の機構での ATP 生成が 推定された16。

先に述べたように，T， halophilus D10株にアスパラ ギン酸を与えてもATP生成は観察されなかったが，ア スパラギン酸脱炭酸プラスミド $\mathrm{pD} 1$ のスパラギン酸脱 炭酸をコードする遺伝子断片を，大腸菌で発現させてア スパラギン酸脱炭酸を行わせた時に, 細胞内ATP濃度 の上昇が見られたわ。すなおち，脱炭酸に共役して何ら 加のエネルギー生成は起こっていることから, 酱油乳酸 菌 T. halophilus のアスパラギン酸脱炭酸に扔いても, Lactobacillus sp. M3株の場合と同様のエネルギー生 成が起こっている可能性が高いと考元られた。

\section{5. アスパラギン酸脱炭酸菌利用技術の将来の展望}




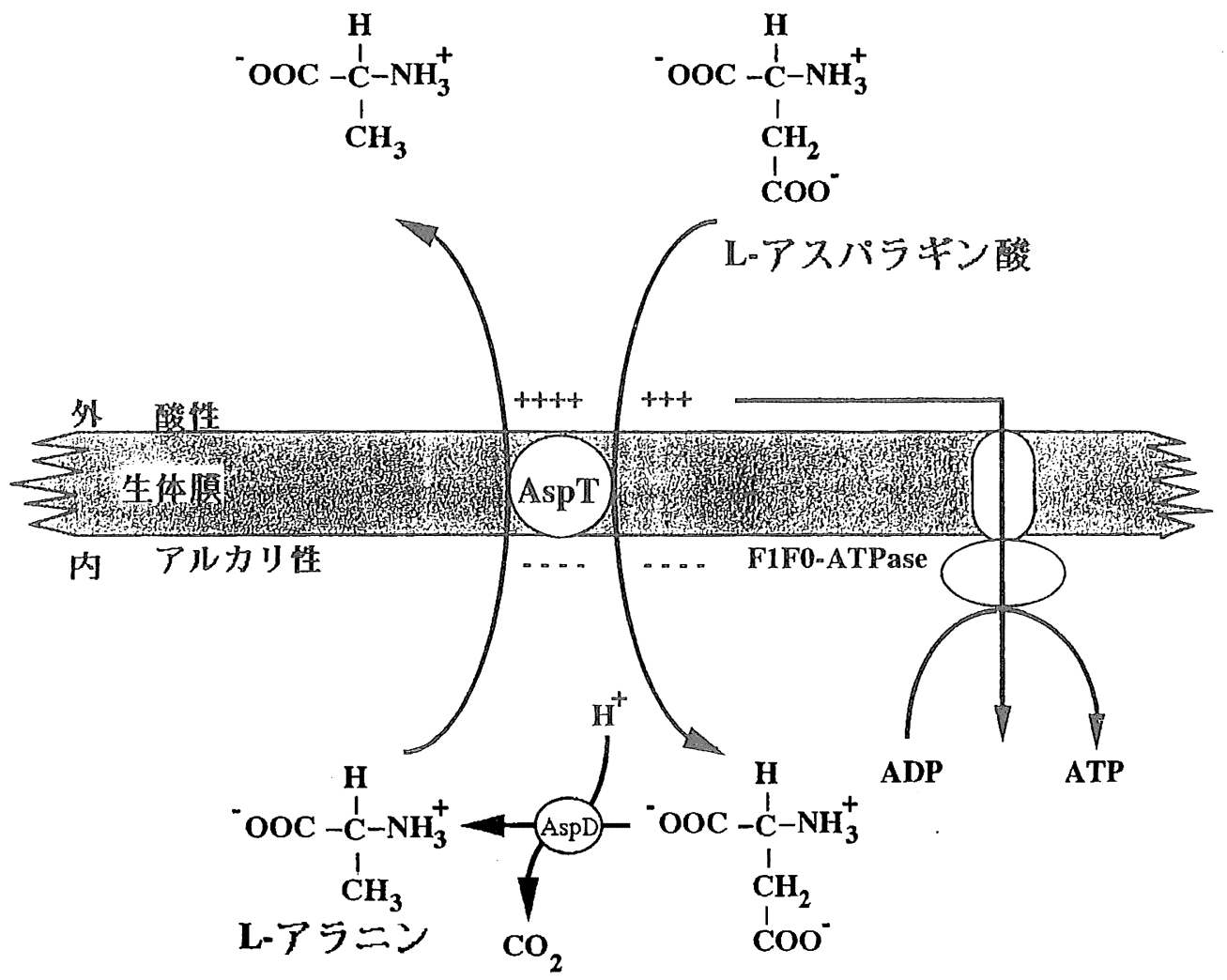

図 5.アスパラギン酸脱炭酸に伴うATP生成モデル

アスパラギン酸は antiporter（AspT）により細胞内のアラニンと交換輸送される。この electrogenic な antiportにより $\Delta \phi$ が生成する。細胞内に取込まれたアスパラギン酸は脱炭酸さ れてアラニンと $\mathrm{CO}_{2}$ を生成し、この時 $\mathrm{H}^{+}$消費して細胞内をアルカリ化して $\Delta \mathrm{pH}$ が発生する。 $\Delta \phi$ と $\mathrm{pH}$ は $\mathrm{F}_{1} \mathrm{~F}_{0}$-ATPaseによるATP生成に利用される。

アスパラギン酸脱炭酸性乳酸菌株の添加は，まろやか な酱油を製造するために有効な手段であるが，奨油醇造 か開放系であるため, ファージ污染や野生乳酸菌との競 合等のため，これまでは完全に添加菌をコントロールす るのは困難であった。しかしながら，ファージ抵抗性株 育種によりファージ污染を防ぐことができた。ここで示 したファージ抵抗性株育種の技術は，他の菌株にも応用 可能であろう。

また多くの乳酸菌でプラスミドの接合伝達が観察され ていることから，アスパラギン酸脱炭酸をコードするプ ラスミドが明らかになったことで, 接合伝達や形質転換 より, 增殖力の強い菌株にアスパラギン酸脱炭酸性を付 与できる可能性む出てきた。また, この遺伝子をクロモ ゾームに組み込むことにより，アスパラギン酸脱炭酸性 の遺伝的不安定性す解消されることが期待される。 さらに，アスパラギン酸脱炭酸によりエネルギーが生
成していると考えられるので，脱炭酸活性を上げること で, 菌のATP生成力を増強し, 野生乳酸菌之の競合に 有利な株を造成することあ出来る可能性がある。そうな れば従来，優れた性質を持ちながら，增殖速度が遅いた め, 実用株として使用できなかったような菌株の増殖力 を強化することも出来ると期待される。この技術は, 塩

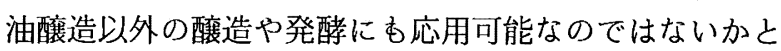
思われる。

$$
\text { 文 献 }
$$

1) Stratton, J. E., Hutkins, R. W., and Taylor, S. L.: Biogenic amines in cheese and other fermented foods: a review. J. Food Sci., 54, 460-470 (1991).

2) Uchida, K.: Trends in preparation and uses of fermentation and acid-hydrolyzed soy sauce. In "Proceedings of the world congress on vegetable protein utilization in human foods and animal feedstuffs" ed. by Applewhite, T. H., American Oil Chemists' Society, pp. 78-83 (1989).

3）内田金治：酱油醸造における乳酸菌の多㥞性と応用, 酾造 
協会誌，77，740-742（1982）

4) Higuchi, T., Uchida, K., and Abe, K.: Aspartate decarboxylation encoded on the plasmid in the soy sauce lactic acid bacterium, Tetragenococcus halophila D10. Biosci. Biotechnol. Biochem., 62, 1601-1603 (1998)

5) Alexander, F. W., Sandmeier, E., Mehta, P. K., and Christen, P.: Evolutionary relationships among pyridoxal-5'-phosphate-dependent enzymes: regio-specific $\alpha, \beta$, and $\gamma$ famillies. Eur. J. Biochem., 219, 953-960 (1994).

6) Maloney, P. C., and Wilson, T. H.: Ion-coupled transport and transporters. in "Echerichia coli and Salmonella: cellular and molecular biology" eds. by Neidhardt, F. et al., American Society of Microbiology, Washington D. C., pp. 1130-1148 (1996)

7）阿部敬悦 : 未発表デー夕

8) Higuchi, T., Uchida, K., and Abe, K.: Preparation of phage-insensitive strains of Tetragenococcus halophila and its application for soy sauce fermentation. Biosci. Biotechnol. Biochem., 63, 415-417 (1999)

9) Whitehead, H. R., and Cox, G. A.: The occurrence of bacteriophage in cultures of lactic streptococci. N. Z. J. Dairy Sci. Technol., 16, 319-320 (1935).
10) Uchida, K., and Kanbe, C.: Occurrence of bacteriophage lytic for Pediococcus halophilus, a halophilic lactic-acid bacterium, in soy sauce fermentation. J. Gen. Appl. Microbiol., 39, 429-437 (1993).

11) Klaenhammer, T. R., and Fitzgerald, G. F.: Bacteriophages and bacteriophage resistance. In "Genetics and biotechnology of lactic acid bacteria" eds by Gasson, M. J. and de Vos, W. M., Blackie Academic \& Professional, pp. 106-168 (1994)

12) Abe, K., Hayashi, H., and Maloney, P. C.: Exchange of aspartate and alanine. J. Biol. Chem., 271, 3079-3084 (1996)

13) Cox, D. J., and Henick-Kling, T.: Chemiosmotic energy from malolactic fermentation. J. Bacteriol., 171, 5750-5752 (1989)

14）花岡嘉夫 : 「奨油保存に関する研究（第6 報）Lactobacillusによる酱油中のグルタミン酸，アスパラギン酸の分解 について」, 発工, 45，312-314（1967）

15) Anantharam, V., Allison, M. J., and Maloney, P. C.: Oxalate: formate exchange. The basis for energy coupling in Oxalobacter. J. Biol. Chem. 264, 7244-7250 (1989)

16) Higuchi, T., Hayashi, H., and Abe, K.: Exchange of glutamate and $\gamma$-aminobutylate in a Lactobacillus strain. J. Bacteriol., 179, 3362-3364 (1997)

\title{
Aspartate decarboxylation of lactic acid bacteria
}

\author{
Takeshi HiguchI, Kinji Uchida, and Keietsu AвE \\ Research and development Division, Kikkoman Corporation, \\ 399 Noda, Noda City, Chiba 278-0037, Japan
}

Aspartate in soy sauce moromi was sometimes decarboxylated into alanine by the strains of soy sauce lactic acid bacteria, Tetragenococcus halophilus. Because this amino acid conversion makes taste of soy sauce milder, aspartate decarboxylating strain $\left(\mathrm{Asd}^{+}\right.$strain) of $T$. halophilus is important strains in soy sauce manufacturing.

T. halophilus D10 is an $\mathrm{Asd}^{+}$strain. Curing treatment of this strain generated derivative strains that could not cause aspartate decarboxylation (Asd ${ }^{-}$strains). This trait was coded on a $22 \mathrm{~kb}$ plasmid named $\mathrm{pD} 1$. On this plasmid aspartate transporter and aspartate decarboxylase genes formed operon.

Continuous usage of a single strain of lactic acid bacteria in large scale industrial manufacturing cause bacteriophage infection, so phage insensitive strain of D10 strain was prepared to use this $\mathrm{Asd}^{+}$strain in the factory without phage infection.

Physiological reason of aspartate decarboxylation of T. halophilus is not clear yet. However, another lactic acid bacteria which cause aspartate decarboxylation, Lactobacillus sp. M3, derive energy as proton-motive force coupled with the decarboxylation. It is assumed that energy production by similar mechanism occurred in $\mathrm{Asd}^{+}$strain of T. halophilus.

Key Words : soy sauce, Tetragenococcus halopilus, bacteriophage, plasmid, aspartate decarboxylation 